\title{
味噌漬け，酒粕漬けが魚肉のたんぱく質，遊離アミノ酸 およびテクスチャーに与える影響
}

\author{
海老塚広子*・青木麻実*・塩谷一紗** \\ (*東京家政大学, **防衛医科大学校 抗加齢血管内科)
}

(平成28年 2 月 22 日受付，平成 28 年 5 月 20 日受理)

\section{Alterations in the texture and protein; the free amino acid contents of fish meat with miso and sake lees}

\author{
Hiroko Ebizuka*, Mami Aoki *, Kazusa Shiotani** \\ * Tokyo Kasei University, 1-18-1, Kaga, Itabashi-ku, Tokyo, 173-8602 \\ ** Division of Anti-aging and Vascular Medicine, National Defense Medical College, \\ 3-2, Namiki, Tokorozawa-shi, Saitama, 359-8513 \\ *\%173-8602 東京都板橋区加賀 1-18-1 \\ ***359-8513 埼玉県所沢市並木 3-2
}

\begin{abstract}
We investigated alterations in the quality of misozuke and sakekasuzuke prepared with sablefish, traditional processing and cooking methods whereby fish meat is cured in miso or sakekasu (sake lees), respectively. SDS-PAGE patterns of the fish meat revealed protein decomposition during preservation by the enzymes present in miso or sakekasu. We analyzed the levels of free amino acids in sablefish misozuke and sakekasuzuke using an amino acid analyzer. The amino acids found in miso and sakekasu permeated the fish meat and altered the amino acid composition, significantly increasing the umami amino acid content. Further, the meat texture was measured using a creep meter. While the texture of cooked misozuke fish was very firm; less firm than that observed in heated sakekasuzuke. It is proposed that the fish flavor and palatability can be explained by the synergistic effects between miso or sakekasuzuke and the unique fish flavors.
\end{abstract}

\section{1. 緒言}

日本人は, 1 人 1 日当たり約 $80 \mathrm{~g}$ の魚介類を摂取し ており ${ }^{1)}$ ，その量は食事から摂取するたんぱく質の約 2 割, 動物性たんぱく質の約 4 割を占めている。日本の国 民 1 人 1 年当たり供給食料（2011年）（試算）をみると， 魚介類は $48.8 \mathrm{~kg}$ であり, 諸外国と比較して顕著に高い 数值を示していることからも, 世界有数の魚介類消費国

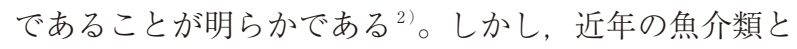
肉類の国民 1 人 1 日当たり摂取量をみると, 魚介類は長 期的に減少しているのに対し, 肉類の摂取量は変化が少 ない。平成18年には肉類の摂取量が魚介類を上回り, 平 成25年には肉類と魚介類の摂取量の差が拡大している ${ }^{1)}$ 。 特に若い世代において, 魚の消費量が低下して魚離れが
進んでいる。また，摂取する魚の種類にも変化がみられ ている。消費量の高い魚を比較すると, 昭和 40 年代はイ カ, アジ, サバなどであったが, 平成 22 年にはイカ, サ

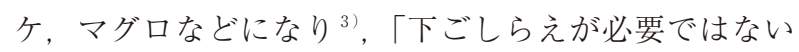
切り身, 刺身あるいは干物などが増加している」「鮮魚 店ではなく, スーパーマーケットからの購入が増加して いる」などが理由としてあげられる。

日本人の食生活は第 2 次世界大戦以降に, 動物性たん ぱく質と脂質の供給熱量が増加し, 炭水化物の供給熱量 においては減少している。これに伴い, 日本人の死因も 感染症や脳血管疾患などから悪性新生物などの生活習慣 病へと変化してきた。魚介類の栄養学的特徵としては, IPA や DHA などの高度不飽和脂肪酸を含有しているこ とである。これらは, 心血管系疾患やがんの予防, 脳神 
経系組織の機能発現, 血中コレステロールや血中脂質の 上昇を抑制するという報告がある ${ }^{4)}$ 。タウリンには血中 コレステロール低下作用など，魚肉たんぱく質を酵素処 理して得られるぺプチドには ACE 阻害活性を有するも のが見出されている。

日本には，刺身や寿司などに代表される生食嗜好の魚 食文化がある一方，魚介類を漬けて保存性を高めると いった加工もなされてきた。味噌漬けや酒粕漬けなどの 魚介類の漬物は保存性と喏好性の向上を目的とした伝統 的な加工法である。味噌漬けに関する研究では, 下村ら は魚肉の味噌漬けによるテクスチャーやたんぱく質分解 への影響を報告しており ${ }^{5,6)}$, 山崎らは魚肉の味噌漬け 処理中に味噌や魚肉のペプチドが魚肉脂質の酸化を防止 することなどを報告している ${ }^{7,8)}$ 。酒粕漬けに関しては, 魚肉のたんぱく質の変化 ${ }^{9)}$ や鷄肝臓を酒粕に漬け込んだ ときに食味，性状の変化や保存性に与える影響10) あるい は，酒粕に含まれているペプチドによる血圧上昇抑制効 果などが報告されている

本研究では，たんぱく質よりも脂質が多いという特徵 を有するギンダラ肉を味噌漬け掞よび酒粕漬けにした場 合のたんぱく質，遊離アミノ酸組成，テクスチャーへ与 える影響について検討した。

\section{2. 実験方法}

\section{（1）実験材料}

魚肉は，ギンダラ（カサゴ目ギンダラ科ギンダラ属ギ ンダラ Anoplopoma fimbria) の冷凍品を使用した。使用 時まで, $-40^{\circ} \mathrm{C}$ の冷凍庫内にて保存した。味噌は，ひか り味噌株式会社 $\mathrm{HG}$ 製米味噌を用いた。味噌の成分は有 機大豆（遺伝子組及換えでない），米（国産）, 食塩であ る。酒粕は，山田酒造食品株式会社製を用いた。酒粕の 成分は，米，米麹，アルコール，水あめである。

\section{（2）SDS-PAGE および遊離アミノ酸の定量に用いる 試料の調製}

ギンダラ肉は冷蔵庫内で解凍した後, 筇線維と直角に なるように切断し, 各試料の厚さ $1.5 \mathrm{~cm}$, 重量 $30 \pm 1 \mathrm{~g}$ に揃えて切り身にした。これを未処理ギンダラ肉とした 味噌漬け処理は, 未処理ギンダラ肉と同重量の味噌で周 囲を覆い，味噌漬けギンダラ肉とした。酒粕漬け処理は， 未処理ギンダラ肉と同重量の酒粕で周囲を覆い，酒粕漬 けギンダラ肉とした。それぞれの試料 $(n=5)$ を食品 包装用ラップフィルムに一切れずつ包み， $4{ }^{\circ} \mathrm{C}$ の冷蔵庫 にて $1 ， 3 ， 5$ 日間保存した。

味噌漬けギンダラ肉は，冷蔵庫で $1 ， 3 ， 5$ 日間保存 後，ギンダラ肉周囲の余分な味噌を薬さじで丁寧に除き， キムワイプで軽く押さえる程度に拭き取り，漬味噌捛よ び味噌漬けギンダラ肉を実験に用いた。また，酒粕漬け ギンダラ肉も同様に, 冷蔵庫で $1,3 ， 5$ 日間保存後, 余分な酒粕を薬さじで丁寧に除き，キムワイプで軽く押
さえる程度に拭き取り，漬酒粕および酒粕漬けギンダラ 肉を実験に用いた。対照として未処理ギンダラ肉も用意 した。

\section{（3）SDS-PAGE による分析}

未処理ギンダラ肉と味噌漬けギンダラ肉および漬味噌, 酒粕漬けギンダラ肉および漬酒粕について，SDS-PAGE 分析を行った。

泳動試料の調製は次のように行った。未処理ギンダラ 肉, 味噌漬けギンダラ肉 $(1,3,5$ 日間漬けた肉), 酒 粕漬けギンダラ肉（1，3，5 日間漬けた肉）をミンサー でミンチにした後， $0.01 \mathrm{~mol} / \mathrm{L}$ リン酸緩衝液（pH 7.7） を加えて摩砕した。漬味噌と漬酒粕についても, 同様に 処理を行った。遠心分離を行い, 試料液を希䣋した後, SDS 変性紸衝液を混和し, 加熱処理後に泳動試料とした。 分析は，スラブ型電気泳動装置（アトー侏）を用い，ゲ ル濃度は 5 ～20\%，染色液はクマシーブリリアントブ ルーを用いた。

\section{（4）遊離アミノ酸の定量}

未処理ギンダラ肉，味噌漬けギンダラ肉（3，5 日間 漬けた肉)，酒粕漬けギンダラ肉（3，5 日間漬けた肉） をミンチ状にしてから水を加えて摩砕・抽出し，遠心分 離した。試料溶液に $2 \%$ \%ルホサリチル酸溶液を加えて 摚拌した後，遠心分離した。上澄み液をフィルター処理 し，遊離アミノ酸の定量に用いる試料とした。漬味噌と 漬酒粕も同様に処理を行った。ニンヒドリン試薬を用い て，アミノ酸分析計（機種：日立高速液体クロマトグラ フ LaChrom Elite (陎日立製作所，カラム：\#2622PF イ オン交換樹脂 $4.6 \mathrm{~mm}$ I.D. $\times 60 \mathrm{mmL}$ (陎日立ハイテク) ロジーズ, 移動相：L-8500PF 緩衝液, 反応液：ニンヒ ドリン試薬）で測定した。アミノ酸混合標準液は $\mathrm{AN}-$ II 型，B 型（和光純薬工業(秼）を用いた。

\section{（5）テクスチャー解析}

1) 漬け込み方法

ギンダラ肉は，皮と骨を取り除き，筋線維と直角にな るように, $3 \mathrm{~cm} \times 3 \mathrm{~cm}$, 厚さ $1.5 \mathrm{~cm}$ ，重量約 $14 \sim 18 \mathrm{~g}$ の切り身にした。切り身の $50 \%$ 重量の酒粕と味噌を切り 身の周囲に付着させ，その後ラップフィルムに一切れず つ包み, $4{ }^{\circ} \mathrm{C}$ の冷蔵庫に 3,5 日間保存した。対照とし て未処理ギンダラ肉を準備した。味噌漬けギンダラ肉, 酒粕漬けギンダラ肉は，3 日間抄よび5 日間保存した後, 各々の漬床を薬さじで丁寧に除き，キムワイプで軽く押 さえる程度に拭き取り加熱試料とした。各試料 3 切れず つ，合計15切れを準備した。

\section{2) 加 熱}

クッキングシートを敷いた円型天板にギンダラ肉をの せ，予熱して掠いたコンベックオーブン（RMC-S12E リ ンナイ(怢) で $200^{\circ} \mathrm{C}, 9$ 分間加熱した。中心温度計 
M

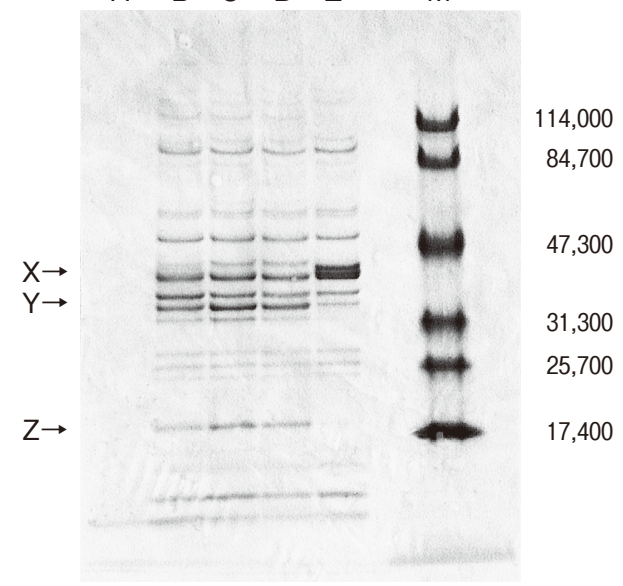

図 1 味噌漬けギンダラ肉および味噌の電気泳動図

$\mathrm{A}$ ：味噌 B：味噌漬けギンダラ肉 1 日目

C: 味噌漬けギンダラ肉 3 日目

D: 味噌漬けギンダラ肉 5 日目

$\mathrm{E}$ ：未処理ギンダラ肉 $\mathrm{M}$ ：分子量マーカー

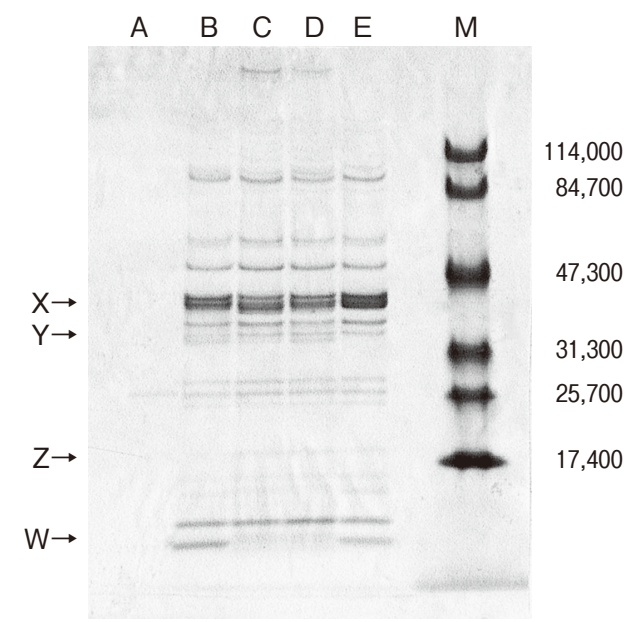

図 2 酒粕漬けギンダラ肉および酒粕の電気泳動図

$\mathrm{A}$ : 酒粕 B: 酒粕漬けギンダラ肉 1 日目

C: 酒粕漬けギンダラ肉 3 日目

D: 酒粕漬けギンダラ肉 5 日目

$\mathrm{E}$ ：未処理ギンダラ肉 $\mathrm{M}$ ：分子量マーカー
（MF1000 侏チノー）を用い, 中心温度が $75^{\circ} \mathrm{C}$ 以上になっ たことを確認し，水分蒸発を防ぐためプラスチック製の 容器に移し蓋をずらして置き，中心温度が約 $50^{\circ} \mathrm{C}$ になる まで10分間，室温に放置した。

\section{3) 測 定}

未処理ギンダラ肉と味噌漬け, 酒粕漬けギンダラ肉(漬 け込み 3 日目と 5 日目）についてテクスチャーの測定を した。測定は,クリープメータ（TPU-2S 侏山電）を 用いて室温で行った。測定条件は, 円柱状プランジャー 径 $8 \mathrm{~mm}$, 試料の高さ $15 \mathrm{~mm}$, クリアランス $5 \mathrm{~mm}$, 試 料台速度 $2.5 \mathrm{~mm} / \mathrm{sec}$, 運動回数 2 回とした。測定項目は, 硬さ，もろさとした。加熱したギンダラ肉は，筋線維と 同方向にプランジャーを当てるように置いた。物性值は, 各試料 3 切れの測定平均值で示した。テクスチャー曲線 の記録抢よび解析は, ソフトウェア山電 破断強度解析 ・テクスチャー解析・クリープ解析（株山電）を用いた。

\section{(6) 統計処理}

統計解析には,ソフトウェア「Excel 統計2012」を用い, 有意水準は $5 \%$ 未満とした。分散分析で有意差検定を行 い，有意差が確認された場合にはさらに多重比較 (Tukey)を行った。

\section{3.結果および考察}

（1）味噌漬けと酒粕漬けによるギンダラ肉および漬味 噌と漬酒粕の SDS-PAGE

未処理ギンダラ肉, 味噌漬けギンダラ肉, 酒粕漬けギ ンダラ肉, 漬味噌拐よび漬酒粕を SDS-PAGE 分析した 結果を図 1 , 図 2 に示した。

味噌漬けギンダラ肉, 酒粕漬けギンダラ肉は未処理ギ ンダラ肉と比較して, 漬け込み $1 ， 3 ， 5$ 日目に打いて 泳動パターンに変化が認められた。1日目，3日目に対
して5日目では顕著な差異はみられなかった。未処理ギ ンダラ肉に検出された分子量約40,000の画分 $(\mathrm{X})$ が味 噌漬けの期間を追うごとに分解され，約 $30,000 〜 40,000$ のバンド $(\mathrm{Y})$ や約 $17,000 〜 18,000$ のバンド $(\mathrm{Z})$ が検 出された（図 1 )。これは味噌由来のたんぱく質では存 在していないバンドであるため, 未処理ギンダラ肉のた んぱく質が味噌漬け処理をしたことにより低分子化して 分解されたことが示された。また，未処理ギンダラ肉で は認められない約 $30,000 〜 40,000$ のバンド (Y) が酒粕 漬けギンダラ肉で検出された (図 2 )。酒粕漬けギンダ ラ肉 3 日目, 5 日目に打いては, 約 $17,000 〜 18,000$ のバ ンド $(Z)$ が検出された。一方, 未処理ギンダラ肉に存 在する約 20,000 のバンド (W) は, 酒粕漬け 3 日目, 5 日目に执いては消失した。以上の結果より, 味噌漬けギ ンダラ肉, 酒粕漬けギンダラ肉ともにたんぱく質が分解 されていることが明らかになった。また，味噌漬けと酒 粕漬けとの比較をすると味噌漬けのほうがたんぱく質の 低分子化に与える影響が強いことが判明した。

酒粕は清酒を製造するときにできる副産物であり，清 酒の原料は米, 水, 種趜 (Aspergillus oryzae), 清酒酵母 (Saccharomyces cerevisiae) である。一方，味噌は大豆，米， 種凊 (Aspergillus oryzae)，食塩である。清酒の種趋は主 に米のでんぷん糖化に利用され，味噌の種鈿は大豆や米 に含まれるたんぱく質の分解とでんぷん糖化の役割を 果たしている。そのため, 味噌に使わ机るAspergillus oryzae はアミラーゼとプロテアーゼ活性がより強いもの が用いられており，酒粕に比べてギンダラ肉のたんぱく 質をより低分子化したのではないかと推察された。植物 由来のプロテアーゼであるブロメラインやパパインなど は，食肉の触感を軟らかくするために食肉軟化剤として 利用されることがある。これらは食肉の筋線維を構成す るアクチンやミオシン, 結合組織であるコラーゲンなど 
表 1 ギンダラ肉の味噌漬け期間による遊離アミノ酸量の変化 $(\mathrm{mg} / 100 \mathrm{~g})$

\begin{tabular}{|c|c|c|c|c|c|c|c|c|c|c|}
\hline \multirow[b]{3}{*}{ Asp } & \multirow[b]{3}{*}{$*$} & \multicolumn{9}{|c|}{ ギンダラ肉の味噌漬け期間（日数） } \\
\hline & & \multicolumn{3}{|c|}{0} & \multicolumn{3}{|c|}{3} & \multicolumn{3}{|c|}{5} \\
\hline & & 1.3 & \pm & 0.0 & 42.6 & \pm & 2.2 & 53.7 & \pm & 0.3 \\
\hline Glu & $*$ & 2.8 & \pm & 0.2 & 55.5 & \pm & 3. 0 & 69.5 & \pm & 0.4 \\
\hline Ala & $* *$ & 6.0 & \pm & 0.2 & 30.2 & \pm & 1.7 & 36.6 & \pm & 0.4 \\
\hline Gly & $* *$ & 2.1 & \pm & 0.1 & 13. 2 & \pm & 0.7 & 15.9 & \pm & 0.2 \\
\hline Ser & $* *$ & 2.1 & \pm & 0.0 & 26.4 & \pm & 1.4 & 32.5 & \pm & 0.2 \\
\hline Thr & $* *$ & 1.9 & \pm & 0.0 & 16.1 & \pm & 0.9 & 19.7 & \pm & 0.2 \\
\hline $\operatorname{Arg}$ & $* * *$ & 1.6 & \pm & 0.3 & 46.9 & \pm & 2.6 & 60.0 & \pm & 1.3 \\
\hline His & $* * *$ & 0.8 & \pm & 0.1 & 4.7 & \pm & 0.5 & 6.2 & \pm & 0.6 \\
\hline Ile & $* * *$ & 0.9 & \pm & 0.1 & 21.0 & \pm & 1.1 & 27. 2 & \pm & 0.9 \\
\hline Leu & $* * *$ & 1.4 & \pm & 0.1 & 42.4 & \pm & 2.3 & 53.8 & \pm & 1. 1 \\
\hline Val & $* * *$ & 0.9 & \pm & 0.1 & 5.7 & \pm & 0.4 & 9.1 & \pm & 0.9 \\
\hline Cys & & 3.1 & \pm & 0.1 & 44.4 & \pm & 2.4 & 56.5 & \pm & 1. 1 \\
\hline Lys & & 10.5 & \pm & 0.2 & 37.4 & \pm & 2.1 & 47.4 & \pm & 0.4 \\
\hline Tyr & & 0.9 & \pm & 0.1 & 17.7 & \pm & 0.9 & 24.4 & \pm & 1.1 \\
\hline umami & $*$ & 4.1 & \pm & 0.2 & 98.1 & \pm & 5.2 & 123.3 & \pm & 0.6 \\
\hline sweetness & $* *$ & 12.2 & \pm & 0.3 & 85.9 & \pm & 4. 6 & 104.7 & \pm & 0.9 \\
\hline bitterness & $* * *$ & 5.6 & \pm & 0.4 & 120.7 & \pm & 6.5 & 156.2 & \pm & 2.9 \\
\hline Total & & 36.6 & \pm & 0.5 & 404.1 & \pm & 21.6 & 512.4 & \pm & 6.1 \\
\hline
\end{tabular}

5 回の平均値土標準偏差を示す。

注）Tukeyの検定により０日目と３日目，０日目と５日目，3日目と5日目の間に $5 \%$ の危険率ですべてにおい て有意な差異があった。

表 2 ギンダラ肉の味噌漬け期間による漬味噌に含まれる遊離アミノ酸量の変化（mg/100 g）

\begin{tabular}{|c|c|c|c|c|c|c|c|c|c|c|c|c|c|}
\hline \multirow[b]{3}{*}{ Asp } & \multirow[b]{3}{*}{$*$} & \multicolumn{12}{|c|}{ ギンダラ肉の味噌漬け期間（日数） } \\
\hline & & \multicolumn{3}{|c|}{0} & \multirow[b]{2}{*}{$\mathrm{a}$} & \multicolumn{3}{|c|}{3} & \multirow[b]{2}{*}{$\mathrm{a}$} & \multicolumn{3}{|c|}{5} & \multirow[b]{2}{*}{$\mathrm{a}$} \\
\hline & & 154.4 & \pm & 2.2 & & 109.1 & \pm & 0.9 & & 95.3 & \pm & 2.2 & \\
\hline Glu & $*$ & 198. 0 & \pm & 2.8 & $\mathrm{a}$ & 133.8 & \pm & 7.4 & $\mathrm{a}$ & 115.5 & \pm & 5.1 & $\mathrm{a}$ \\
\hline Ala & $* *$ & 88.6 & \pm & 1. 2 & $\mathrm{a}$ & 59.6 & \pm & 2.2 & $\mathrm{a}$ & 50.6 & \pm & 2.8 & $\mathrm{a}$ \\
\hline Gly & $* *$ & 40.6 & \pm & 0.5 & $\mathrm{a}$ & 27.8 & \pm & 0.7 & $\mathrm{a}$ & 23.8 & \pm & 0.6 & $\mathrm{a}$ \\
\hline Ser & $* *$ & 86.1 & \pm & 1. 2 & $a b$ & 50.3 & \pm & 9.3 & $\mathrm{a}$ & 44.2 & \pm & 8.2 & b \\
\hline Thr & $* *$ & 51.3 & \pm & 0.7 & $\mathrm{a}$ & 33.5 & \pm & 2.9 & $\mathrm{a}$ & 29.2 & \pm & 2.3 & $\mathrm{a}$ \\
\hline $\operatorname{Arg}$ & $* * *$ & 169.3 & \pm & 3.9 & $\mathrm{a}$ & 108.5 & \pm & 12.4 & $\mathrm{a}$ & 86.8 & \pm & 3.7 & $\mathrm{a}$ \\
\hline His & $* * *$ & 15.6 & \pm & 1.5 & $\mathrm{ab}$ & 9.4 & \pm & 1. 2 & $\mathrm{a}$ & 7.6 & \pm & 1.0 & $\mathrm{~b}$ \\
\hline Ile & $* * *$ & 72.6 & \pm & 1. 1 & $\mathrm{a}$ & 47.5 & \pm & 0.7 & $\mathrm{a}$ & 41.7 & \pm & 0.5 & $\mathrm{a}$ \\
\hline Leu & $* * *$ & 146.0 & \pm & 2.1 & $\mathrm{a}$ & 96.1 & \pm & 1. 3 & $\mathrm{a}$ & 84.3 & \pm & 1.0 & $\mathrm{a}$ \\
\hline Val & $* * *$ & 25.2 & \pm & 0.3 & $\mathrm{a}$ & 12.4 & \pm & 0.7 & $\mathrm{a}$ & 11.3 & \pm & 0.4 & $\mathrm{a}$ \\
\hline Cys & & 146.1 & \pm & 2. 2 & $\mathrm{a}$ & 94.0 & \pm & 1. 9 & $\mathrm{a}$ & 83.3 & \pm & 0.6 & $\mathrm{a}$ \\
\hline Lys & & 119.5 & \pm & 2.0 & $\mathrm{a}$ & 84.3 & \pm & 2.4 & $\mathrm{a}$ & 75.5 & \pm & 2.5 & $\mathrm{a}$ \\
\hline Tyr & & 77.1 & \pm & 1.1 & $\mathrm{ab}$ & 49.6 & \pm & 6.1 & $\mathrm{a}$ & 43.2 & \pm & 6.1 & $\mathrm{~b}$ \\
\hline umami & $*$ & 352.4 & \pm & 5.0 & $\mathrm{a}$ & 242.9 & \pm & 3.7 & $\mathrm{a}$ & 210.8 & \pm & 7.5 & $\mathrm{a}$ \\
\hline sweetness & $* *$ & 266.6 & \pm & 7.9 & $\mathrm{a}$ & 171.1 & \pm & 13.2 & $\mathrm{a}$ & 147.9 & \pm & 13.4 & $\mathrm{a}$ \\
\hline bitterness & $* * *$ & 428.7 & \pm & 5.9 & $\mathrm{a}$ & 273.9 & \pm & 9.4 & $\mathrm{a}$ & 231.6 & \pm & 4. 2 & $\mathrm{a}$ \\
\hline Total & & 1390.3 & \pm & 20.8 & $\mathrm{a}$ & 915.8 & \pm & 17.2 & $\mathrm{a}$ & 792.3 & \pm & 8.2 & $\mathrm{a}$ \\
\hline
\end{tabular}

5 回の平均値土標準偏差を示す。

注）同一記号間で, Tukeyの検定により0日目と 3 日目，0日目と 5 日目，3 日目と 5 日目の間に $5 \%$ の危険率で有意な 差異があった。

を分解し，食肉表面の軟化を起こす 12.13 。味噌や酒粕に 漬けることにより，ギンダラ肉のたんぱく質は低分子化 していることが判明した。

（2）味噌漬けと酒粕漬けによるギンダラ肉および漬味 噌と漬酒粕に含まれる遊離アミノ酸の変化

遊離アミノ酸, イノシン酸, 有機酸,ペプチドなどは
呈味成分として，おいしさの発現に寄与している。未処 理ギンダラ肉と比べて, 味噌漬けギンダラ肉や酒粕漬け ギンダラ肉の遊離アミノ酸量に変化が認められるか, ま た漬味噌や漬酒粕に含まれる遊離アミノ酸の変動につい て検討した結果を表 $1 \sim 4$ に示した。数值は 5 回の平均 值を示した。

$100 \mathrm{~g}$ 中の遊離アミノ酸含量の合計值の平均は, 未処 
味噌漬け，酒粕漬けが魚肉のたんぱく質，遊離アミノ酸およびテクスチャーに与える影響

表 3 ギンダラ肉の酒粕漬け期間による遊離アミノ酸量の変化 $(\mathrm{mg} / 100 \mathrm{~g})$

\begin{tabular}{|c|c|c|c|c|c|c|c|c|c|c|}
\hline \multirow[b]{3}{*}{ Asp } & \multirow[b]{3}{*}{$*$} & \multicolumn{9}{|c|}{ ギンダラ肉の酒粕漬け期間（日数） } \\
\hline & & \multicolumn{3}{|c|}{0} & \multicolumn{3}{|c|}{3} & \multicolumn{3}{|c|}{5} \\
\hline & & 1.3 & \pm & 0.0 & 62.0 & \pm & 0.9 & 69.7 & \pm & 0.8 \\
\hline Glu & $*$ & 2.8 & \pm & 0.2 & 68.2 & \pm & 1.4 & 76.2 & \pm & 0.9 \\
\hline Ala & $* *$ & 6.0 & \pm & 0.2 & 78.4 & \pm & 1.1 & 85.6 & \pm & 1.0 \\
\hline Gly & $* *$ & 2.1 & \pm & 0.1 & 34.0 & \pm & 0.5 & 37.0 & \pm & 0.4 \\
\hline Ser & $* *$ & 2.1 & \pm & 0.0 & 35.8 & \pm & 0.5 & 40.3 & \pm & 0.5 \\
\hline Thr & $* *$ & 1.9 & \pm & 0.0 & 29.8 & \pm & 0.6 & 33.6 & \pm & 0.4 \\
\hline $\operatorname{Arg}$ & $* * *$ & 1.6 & \pm & 0.3 & 43.5 & \pm & 1.7 & 54.1 & \pm & 0.8 \\
\hline His & $* * *$ & 0.8 & \pm & 0.1 & 15.2 & \pm & 0.4 & 18. 0 & \pm & 0.7 \\
\hline Ile & $* * *$ & 0.9 & \pm & 0.1 & 33.4 & \pm & 0.5 & 37.8 & \pm & 0.4 \\
\hline Leu & $* * *$ & 1.4 & \pm & 0.1 & 51.2 & \pm & 0.5 & 59.1 & \pm & 0.6 \\
\hline Val & $* * *$ & 0.9 & \pm & 0.1 & 10.4 & \pm & 0.1 & 12.5 & \pm & 0.2 \\
\hline Cys & & 3.1 & \pm & 0.1 & 87.2 & \pm & 1.5 & 98.6 & \pm & 0.9 \\
\hline Lys & & 10.5 & \pm & 0.2 & 53.7 & \pm & 0.7 & 61.9 & \pm & 0.8 \\
\hline Tyr & & 0.9 & \pm & 0.1 & 20.7 & \pm & 1.1 & 25.2 & \pm & 1.5 \\
\hline umami & $*$ & 4.1 & \pm & 0.2 & 130.2 & \pm & 2.3 & 145.9 & \pm & 1.7 \\
\hline sweetness & $* *$ & 12.2 & \pm & 0.3 & 178.0 & \pm & 2.6 & 196.5 & \pm & 2.2 \\
\hline bitterness & $* * *$ & 5.6 & \pm & 0.4 & 153.7 & \pm & 3.0 & 181.6 & \pm & 2.4 \\
\hline Total & & 36.6 & \pm & 0.5 & 623.5 & \pm & 9.3 & 709.5 & \pm & 7.9 \\
\hline
\end{tabular}

5 回の平均值士標準偏差を示す。

注）Tukeyの検定により０日目と３日目，０日目と５日目，3日目と5日目の間に $5 \%$ の危険率ですべてにおい て有意な差異があった。

表 4 ギンダラ肉の酒粕漬け期間による漬酒粕に含まれる遊離アミノ酸量の変化（mg/100 g ）

\begin{tabular}{|c|c|c|c|c|c|c|c|c|c|c|c|c|c|}
\hline \multirow[b]{3}{*}{ Asp } & \multirow[b]{3}{*}{$*$} & \multicolumn{12}{|c|}{ ギンダラ肉の酒粕漬け期間（日数） } \\
\hline & & \multicolumn{4}{|c|}{0} & \multicolumn{3}{|c|}{3} & \multicolumn{5}{|c|}{5} \\
\hline & & 110.6 & \pm & 2.6 & $\mathrm{a}$ & 69.6 & \pm & 1.0 & $\mathrm{a}$ & 64.6 & \pm & 1.2 & $\mathrm{a}$ \\
\hline Glu & $*$ & 116.4 & \pm & 2.1 & $\mathrm{a}$ & 72.1 & \pm & 0.7 & $\mathrm{a}$ & 66.5 & \pm & 2.2 & $\mathrm{a}$ \\
\hline $\mathrm{Ala}$ & $* *$ & 123. 4 & \pm & 3.3 & $\mathrm{a}$ & 72.9 & \pm & 1. 2 & $\mathrm{a}$ & 69.4 & \pm & 1.0 & $\mathrm{a}$ \\
\hline Gly & $* *$ & 53.0 & \pm & 1. 6 & $\mathrm{a}$ & 32.1 & \pm & 0.3 & $\mathrm{a}$ & 30.1 & \pm & 0.4 & $\mathrm{a}$ \\
\hline Ser & $* *$ & 55.9 & \pm & 1. 3 & $\mathrm{a}$ & 35.4 & \pm & 0.4 & $\mathrm{a}$ & 32.8 & \pm & 0.8 & $\mathrm{a}$ \\
\hline Thr & $* *$ & 46.9 & \pm & 1. 1 & $\mathrm{a}$ & 29.8 & \pm & 0.2 & $\mathrm{a}$ & 28.2 & \pm & 0.4 & $\mathrm{a}$ \\
\hline Arg & $* * *$ & 74.3 & \pm & 9.1 & $\mathrm{ab}$ & 43.2 & \pm & 5.2 & $\mathrm{a}$ & 40.0 & \pm & 4.5 & $\mathrm{~b}$ \\
\hline His & $* * *$ & 18.8 & \pm & 2.9 & $\mathrm{ab}$ & 12.9 & \pm & 1.4 & $\mathrm{a}$ & 10.8 & \pm & 1.5 & $\mathrm{~b}$ \\
\hline Ile & $* * *$ & 53.2 & \pm & 1. 2 & $\mathrm{a}$ & 34.2 & \pm & 1.8 & $\mathrm{a}$ & 31.0 & \pm & 0.8 & $\mathrm{a}$ \\
\hline Leu & $* * *$ & 82.5 & \pm & 2.5 & $\mathrm{a}$ & 52.7 & \pm & 1.8 & $\mathrm{a}$ & 47.6 & \pm & 1.9 & $\mathrm{a}$ \\
\hline Val & $* * *$ & 14.7 & \pm & 1. 0 & $\mathrm{ab}$ & 9.6 & \pm & 1.5 & $\mathrm{a}$ & 8.3 & \pm & 0.8 & $\mathrm{~b}$ \\
\hline Cys & & 139.8 & \pm & 3.8 & $\mathrm{ab}$ & 91.7 & \pm & 7.4 & $\mathrm{a}$ & 90.0 & \pm & 6.4 & $\mathrm{~b}$ \\
\hline Lys & & 81.6 & \pm & 2.8 & $\mathrm{ab}$ & 52.0 & \pm & 2.3 & $\mathrm{a}$ & 48.7 & \pm & 1.7 & $\mathrm{~b}$ \\
\hline Tyr & & 30.6 & \pm & 1. 0 & $\mathrm{a}$ & 25.9 & \pm & 3.4 & $\mathrm{a}$ & 20.2 & \pm & 3.1 & $\mathrm{a}$ \\
\hline umami & $*$ & 227.0 & \pm & 4. 4 & $\mathrm{a}$ & 141.8 & \pm & 1.5 & $\mathrm{a}$ & 131.1 & \pm & 2.8 & $\mathrm{a}$ \\
\hline sweetness & $* *$ & 279.2 & \pm & 7.1 & $\mathrm{a}$ & 170.1 & \pm & 1.3 & $\mathrm{a}$ & 160.5 & \pm & 2.3 & $\mathrm{a}$ \\
\hline bitterness & $* * *$ & 243.5 & \pm & 13.6 & $a b$ & 152.5 & \pm & 5.9 & $\mathrm{a}$ & 137.7 & \pm & 5.1 & $\mathrm{~b}$ \\
\hline Total & & 1001.7 & \pm & 30.5 & $\mathrm{a}$ & 634.0 & \pm & 15.8 & $\mathrm{a}$ & 588.1 & \pm & 15.9 & $\mathrm{a}$ \\
\hline
\end{tabular}

5 回の平均値土標準偏差を示す。

注）同一記号間で, Tukeyの検定により0日目と 3 日目，0日目と 5 日目，3 日目と 5 日目の間に $5 \%$ の危険率で有意な 差異があった。

理ギンダラ肉で $36.6 \mathrm{mg}$, 味噌漬けギンダラ肉 3 日目 $404.1 \mathrm{mg}$, 5 日目 $512.4 \mathrm{mg}$ であり, 酒粕漬けギンダラ 肉 3 日目 $623.5 \mathrm{mg}, 5$ 日目 $709.5 \mathrm{mg}$ であった。味噌漬 けギンダラ肉と漬味噌のアミノ酸量には, 強い関連性が 認められた。味噌漬けギンダラ肉は日数を経るごとに遊 離アミノ酸が増加したことが確認され, 漬味噌は 3 日目, 5 日目では低下を示した。味噌に含まれている遊離アミ
ノ酸は急激にギンダラ肉へ移行していることが推測され た。また，酒粕漬けギンダラ肉と漬酒粕にも同様に，酒 粕に含まれている遊離アミノ酸がギンダラ肉へと移行し ていた。3日目と5日目ではわずかな増加であった。

旨味を呈する遊離アミノ酸については, 未処理ギンダ ラ肉と比較して, 味噌漬けギンダラ肉 3 日目では 23.9 倍, 5 日目では30.1倍に増加していた。甘味アミノ酸は 3 日 


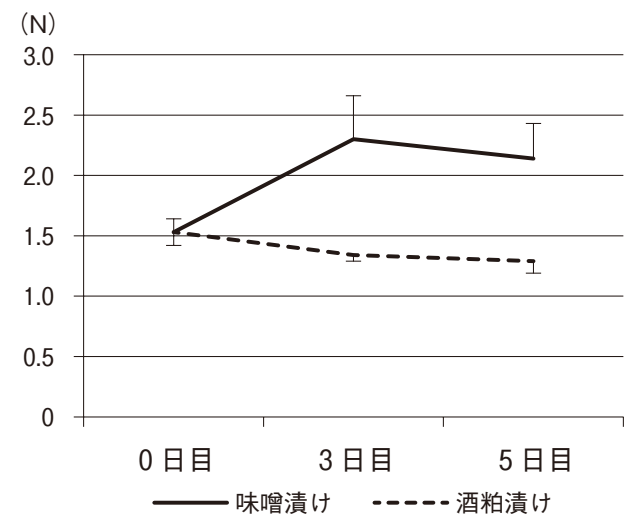

図 3 漬け込み期間による硬さの変化 3 回の平均値士標準偏差を示す。

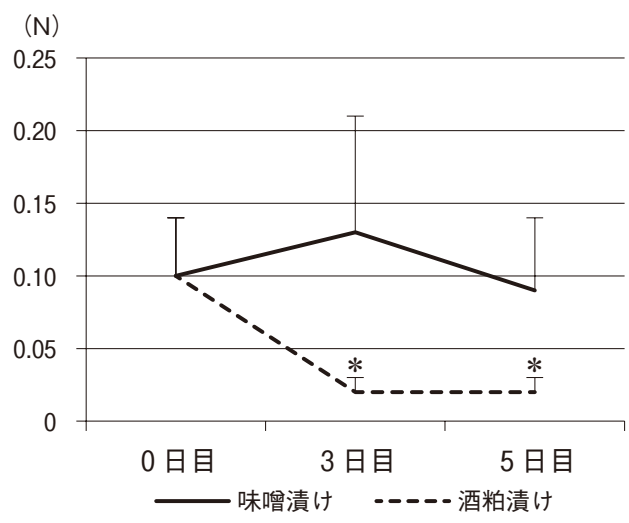

図 4 漬け込み期間によるもろさの変化 3 回の平均值土標準偏差を示す。

*Tukeyの検定により 0 日目と 3 日目， 0 日目と 5 日目 の間に $5 \%$ の危険率で有意な差があることを示す。
目7.0倍，5 日目8.6倍，苦味アミノ酸は 3 日目21.6倍， 5 日目27.9倍に増加していた。旨味を呈するアミノ酸の 増加が最も顕著である傾向は, 酒粕漬けにおいても同様 であった。酒粕漬けギンダラ肉では，各遊離アミノ酸量 は未処理ギンダラ肉と比較して, 旨味 3 日目 31.8 倍, 5 日目35.6倍，甘味 3 日目14.6倍，5 日目16.1倍，苦味 3 日目27.4倍，5日目32.4倍に増加していた。なお，赤身 魚に多く分布するヒスチジンは，苦味アミノ酸であり， ヒスタミンデカルボキシラーゼによりヒスタミンへ変換 されるが，味噌漬けや酒粕漬けをすることにより増加率 は低いアミノ酸であり，白身魚のギンダラ肉においては 低值を示していた。

旨味を呈する遊離アミノ酸であるグルタミン酸やアス パラギン酸は味噌や酒粕に多く含まれている。そのため, 味噌や酒粕に漬けることにより，ギンダラ肉へ移行した ことが推測され，これらの伝統的な調理法は保存性の向 上だけではなく，ギンダラなどの魚介類の旨味の発現に も寄与していることが明らかとなった。味噌漬, 酒粕漬 けにより30倍以上に増加しているアルギニンは, 苦味ア ミノ酸に分類されるが，味の複雑さやこくを高める効果 もある。また，酒粕に多く含まれているアラニンやグリ シンは, 爽快な甘味をもつアミノ酸であり, 甘味に寄与 している。

ギンダラ肉の旨味成分と味噌や酒粕からの遊離アミノ 酸の移行により風味への影響が推察された。また味噌中 のプロテアーゼがギンダラ肉に作用してたんぱく質分解 を起こし，呈味成分の変化を生じていると考えられる。 ギンダラ肉に含まれるイノシン酸と味噌や酒粕に含まれ ているグルタミン酸による旨味の相乗効果が示唆される。

（３）味噌漬けと酒粕漬けによるギンダラ肉のテクス チャーへ与える影響

ギンダラ肉を味噌および酒粕につけた後, 加熱してテ クスチャーを測定した。漬け込み期間による硬さの変化, もろさについて図 3 , 図 4 に示した。
硬さは，一定の変形をさせるのに必要な力であり，未 処理ギンダラ肉と比較して, 味噌漬けギンダラ肉では 3 日目，5日目で硬くなる傾向が認められた。一方，酒粕 漬けギンダラ肉では，未処理ギンダラ肉と比較して 3 日 目，5日目で硬さは低下した。SDS-PAGEの結果では, 味噌漬け処理は，魚肉のたんぱく質を低分子化したこと が確認されたため，味噌漬けによる硬さの低下を予測し たが, 結果は異なっていた。味噌に漬けることにより， 食塩による浸透圧の影響でギンダラ肉中の水分が漬味噌 に移行し，魚肉が硬く変化したことが推測された。なお， 淡色辛味噌の食塩相当量は $100 \mathrm{~g}$ 当たり $12.4 \mathrm{~g}$, 酒粕で は $100 \mathrm{~g}$ 当たり $0 \mathrm{~g}$ であるため味噌漬けは塩分の影響を 強く受けていることが示唆された ${ }^{14)}$ 。

食品を破砕するときの力，すなわちぽろぽろすると いった表現で表すもろさを比較すると，味噌漬けにおい て3 日目で值がやや上昇し 5 日目で低下したが有意な差 異は認められなかった。酒粕漬けでは，3日目，5日目 において未処理ギンダラ肉の值よりも危険率 $5 \%$ で有意 に低くなった。5日間の漬け込み期間では，酒粕漬けと 比較して味噌漬け肉のもろさが高いことが判明した。

これらのことから，ギンダラ肉は味噌漬けにすること で，塩分による影響でギンダラ肉を硬化させ，酵素の作 用でたんぱく質を低分子化することにより口に含むと崩 れるようなぽろぽろとしたテクスチャーを生じることが 示唆された。また，ギンダラ肉を酒粕漬けにすると硬さ は低下するが，崩れるような食感ではなく歯ごたえを残 すような食感になることが推察された。調味料に食材を 漬け込むことは, それぞれ独特の風味やテクスチャーを 味わうことができる。また，揮発性成分によるマスキン グ，アミノカルボニル反応生成物によるマスキングや抗 酸化作用，たんぱく質による魚臭抑制効果もおいしさへ 寄与していることが推測される。

白身魚であるギンダラ肉は，可食部 $100 \mathrm{~g}$ 当たりの脂 質が $17.5 \mathrm{~g}$ ，たんぱく質が $13.0 \mathrm{~g}$ であり，たんぱく質が 少ないという特徴がある ${ }^{14)}$ 。近年の日本人は脂質を多く 
含む魚を好む傾向がある。ギンダラ肉を味噌漬けや酒粕 漬けにすることにより，日本型食生活の重要なたんぱく 質源である魚の摂取量の向上につながることが期待され る。また，味覚感受性が低下して味を感じにくくなる高 齢者に対して，グルタミン酸の摂取を強化することは, 損食量の増加 ${ }^{15}$ や唾液分泌促進 ${ }^{16)}$ などの効果が報告され ている。このことからも，日本型食生活の基本である「だ し」や発酵食品である「味噌」「酒粕」などを食事に取 り入れていくことは有意義であるといえる。

\section{4. 要 約}

ギンダラ肉を用いて，味噌漬けおよび酒粕漬けにして 5 日間保存した場合のたんぱく質, 遊離アミノ酸, テク スチャーに与える影響について検討した。その結果は次 の通りであった。

1. 味噌漬け，酒粕漬けともにギンダラ肉中たんぱく質 の低分子化が認められ，味噌漬けのほうが強い傾向で あった。

2、味噌や，酒粕に含まれている遊離アミノ酸がギンダ ラ肉に移行し，遊離アミノ酸組成に変化を与えた。旨 味に関与する遊離アミノ酸含量が最も顕著に増加した。 3。味噌漬けギンダラ肉を加熱したものは，硬くなる傾 向がありほぽろぼろとした食感になった。それに対し て，酒粕漬けギンダラ肉を加熱したものは，硬さは低 下し，歯ごたえを残すような食感であることが推測さ れた。魚を漬けることは漬け床や食塩の影響を受けて テクスチャーに変化をもたらした。

ギンダラ肉を味噌や酒粕に漬けることは，保存性を高 めるとともに味噌や酒粕などの漬床の材料に由来する微 生物により，魚肉たんぱく質の低分子化へ影響を与えた。 味噌や酒粕由来の遊離アミノ酸の移行により, 旨味甘味, 苦味にかかわる多様なアミノ酸と魚肉に含まれているイ ノシン酸などにより旨味の相乗効果が生じ，風味や挹い しさの発現に寄与することが推察された。魚の漬物とい う伝統的な調理法は魚介類摂取量の向上に役立つことが 期待される。

\section{謝 辞}

本研究の実験にご協力いただきました，松野愛子さん， 奥山陶子さんに深く感謝申し上げます。

\section{文献}

1）厚生労働省：平成25年国民健康 - 栄養調査結果の概要 平成 26 年 12 月 9 日, http://www.mhlw.go.jp/file/04-Houdou happyou-10904750-Kenkoukyoku-Gantaisakukenkouzoushin $\mathrm{ka} / 0000068070 . p d f （ 2015$ 年 3 月 9 日取得）

2 ）農林水産省大臣官房食料安全保障課：食料需給表平成25 年度 平成26年 8 月, http://www.maff.go.jp/j/tokei/kouhyou/ zyukyu/pdf/zyukyu_140805-2.pdf（2015年 3 月 9 日取得）

3）水産庁：平成 22 年度水産白書 “水産物の消費動向”, http://www.jfa.maff.go.jp/j/kikaku/wpaper/h22_h/trend/1/ t1_2_1_1.html（2015年 3 月10日取得）

4) 藤本健四郎, 鴻巣章二：魚の科学, 朝倉書店, 東京, pp.92-99 (1994)

5 ）下村道子, 下坂智恵, 山崎清子：魚肉のみそ漬けにおけ る硬さの変化，家政学雑誌，35，611-619（1994）

6 ）宮内（古根）康衣, 藤浪典子, 市川朝子, 下村道子：調 整味噌漬けサワラ肉とメロ肉の味とテクスチャーの変化 調理科学, 42, 275-284（2009）

7 ）山㠃歌織, 外西壽鶴子, 御木英昌：味噌漬カツオ肉と漬 味噌におけるタンパク質および遊離アミノ酸の変動とプロ テアーゼ活性について, 調理科学, 41，189-195（2008）

8）山嵪歌織：味噌漬魚肉に関する研究, 調理科学, 42, 6470 (2009)

9）下村道子，松本重一郎：カマスサワラ肉の粕漬けにおけ るタンパク質の変化，家政学雑誌，35，687-686（1984）

10）木村友子, 福谷洋子, 加賀谷みえ子：鶏肝臓の熟成酒粕 漬に打ける性状の変化，調理科学，23，267-274（1990）

11） 入江元子, 大浦新, 秦洋二：酒粕中の血圧上昇抑制効果 を持つペプチドと機能性食品素材への展開, 日本醉造協会誌 101, 464-469 (2006)

12）石下真人, 鮫島邦彦：食肉軟化剤としての植物プロテアー ゼ，ニューフードインダストリー，36，53-56（1994）

13）鮫島邦彦, 崔一信, 石下真人, 早川忠昭：食肉軟化剂と してのアクチニジン (キウィフルーツたんぱく質分解酵素) の効果，ニューフードインダストリー，33，56-60（1991）

14）文部科学省科学技術 - 学術審議会資源調査分科会：日本 食品標準成分表2010，全国官報販売共同組合，東京（2010）

15） Bellisle,F., Monneuse,M., Chabert,M., Larue-Achagiotis,C., Lanyeaume,M., Louis-Sylvestre,J.: Monosodium glutamate as palatability enhancer in the European diet. Physiol.Behau, 49, 869-873 (1991)

16) Schiffman,S., Miletic,I.: Effect of taste and smell on secretion rate of salivary IgA in elderly and young persons. Physiol. J. Nutr. Health Aging, 3, 158-164 (1999) 